\title{
New CACNA1A deletions are associated to migraine phenotypes
}

\author{
G. S. Grieco ${ }^{1 \dagger}$, S. Gagliardi ${ }^{1 * \dagger}$ D, I. Ricca', O. Pansarasa', M. Neri ${ }^{2}$, F. Gualandi², G. Nappi ${ }^{3}$, A. Ferlini ${ }^{2}$ and C. Cereda ${ }^{1}$
}

\begin{abstract}
Background: Familial hemiplegic migraine type 1 (FHM1) is a form of migraine with aura caused by heterozygous mutations in 4 genes: CACNA1A, ATP1A2, SNC1A and PRRT2, but further heterogeneity is expected. Here have been described clinical and molecular features in patients suffering from migraine with Aura (MA), without (MO) and hemiplegic migraine attacks.

Next Generation Sequencing by TruSeq Custom Amplicon for CACNA1A and ATP1A2 gene has been performed. All genetic variants have been confirmed by Sanger sequencing and all samples were also analyzed with MLPA assay for ATP1A2-CACNA1A genes to detect duplication or deletion. All MLPA data were verified by Real Time PCR.

Results: Sequencing analysis showed 3 point mutations, two novel variants and one already described in literature. Moreover, MLPA analysis showed 3 deletions in 9 sporadic hemiplegic migraine (18\%), in 3 patients with non-hemiplegic migraine $(4.1 \%)$ and in 3 patients affected by episodic ataxia (20\%). Two sporadic patients showed a deletion in exons $41-43$, while the rest of HM patients (5) showed a deletion in the terminal part of the CACNATA gene.

About episodic ataxia, we have identified deletions in exon 12-15 and in exon 47. Finally, in migraine patients, we have found different subjects affected by different phenotypes deleted in exon 47.

Conclusion: This work highlights the importance to complement analysis as direct sequencing with quantitative analysis (MLPA). In fact, intragenic CACNA1A rearrangements have been detected. Our work demonstrated that deletions in CACNATA gene may be associated also to different migraine phenotypes.
\end{abstract}

Keywords: CACNA1A, Deletion, Migraine phenotypes, De novo

\section{Background}

CACNA1A gene encodes the $\alpha 1$ subunit of neuronal $\mathrm{Ca}_{\mathrm{V}} 2.1$ (P/Q-type) voltage-gated calcium channels that are widely expressed throughout the central nervous system (CNS). Mutations in the CACNA1A gene have been found to be responsible for three disorders with autosomal dominant inheritance: i) Episodic Ataxia 2 (EA2; MIM: 108500), ii) familial hemiplegic migraine type 1 (FHM1; MIM: 141500), and iii) spinocerebellar ataxia type 6 (SCA6; MIM: 183086). Clinical overlap between the three disorders in terms of symptoms has been previously reported [1-3]. Interesting, Pradotto and collaborators [4], described, for the first time, a common mutation in CACNA1A gene in different phenotypes,

\footnotetext{
*Correspondence: stella.gagliardi@mondino.it

${ }^{+}$G. S. Grieco and S. Gagliardi contributed equally to this work.

'IRCCS Mondino Foundation, Genomic and post-Genomic Center, Pavia, Italy Full list of author information is available at the end of the article
}

such as EA2 and SCA6, opening a new prospective about the association between distinct phenotypes caused by the same CACNA1A mutation.

About FHM1, more than 20 missense mutations are known to be associated with a broad spectrum of clinical features besides hemiplegic migraine [5]. Mutations in CACNA1A gene explain around $30-50 \%$ of the FHM cases [5], in fact, other genes as ATP1A2, SCN1A, PRRT2 have been associate to FHM1 disease [5-7].

So far, there is no evidence for works investigating deletions or duplication in CACNA1A in patients FHM1 while in EA2 patients, different deletions [8-10] in CAC$N A 1 A$ gene have been found to lead to loss-of-function of recombinant human $\mathrm{CaV} 2.1$ channels. About the last CACNA1A associated disorder, SCA6 disease, CAC$N A 1 A$ caused the pathology by the expansion of CAG repeat in the $\alpha 1 \mathrm{~A}$ subunit of the voltage-dependent calcium channel gene [11]. 
Moreover, a relevant number of EA2 and FHM cases remain genetically undiagnosed, it can be imputed to incomplete sequencing analysis of the $C A C N A 1 A$ gene, to genetic heterogeneity [12-15] or to the occurrence of CNVs undetectable by exon sequencing. Indeed, in recent years, quantitative analyses as MLPA or QMPSF allowed to identify large genomic deletions involving the $C A C N A 1 A$ gene and associate to EA2 and different $C A C N A 1 A$ related phenotypes.

This work would emphasize the importance of the genetic rearrangement of CACNA1A gene in different phenotype and also to highlight the importance of using multiple techniques, in order to reach a higher diagnostic sensitivity and specificity.

Herein, we present an important screening of $C A C$ $N A 1 A$ gene to identify new point mutations (by Next Generation Sequencing) and to search CNVs (using MLPA assay) in patients affected by hemiplegic migraine, episodic ataxia and, for the first time, in migraine with aura not hemiplegic (MA) and migraine without aura (MO). To perform a complete analysis of $C A C$ $N A 1 A$ gene, we have also investigated the expansion of the CAG repeat in the $\alpha 1 \mathrm{~A}$ subunit of CACNA1A associated to SCA6 phenotype.

\section{Methods}

\section{Patients and controls}

The clinical diagnosis followed the IHS 2nd edition criteria having collected a written informed consent to genetic tests at "C. Mondino" Neurological Institute in Pavia and at the University-Hospital S. Anna in Ferrara.

We collected peripheral blood samples of 50 patients with hemiplegic migraine (36 sporadic and 14 familial cases), of 15 patients with Episodic Ataxia2 (EA2) and of 72 patients with MA or MO. Moreover we enrolled 70 healthy volunteers age 65 years or more after obtaining written informed consent (Table 1).

\section{Sequencing analysis}

We purified genomic DNA from blood by automatic extraction (Maxwell ${ }^{\odot} 16$ Blood DNA - Promega). Next Generation Sequencing by TruSeq Custom Amplicon for CACNA1A, ATP1A2 SCN1A, PRRT2 genes has been performed (Illumina) according to the manufacturers' instructions. DNA analysis has been carried out using Illumina MySeq. All genetic variants have been confirmed by Sanger sequencing, PCR-amplified the 47 exons and 80 base pairs of the flanking intronic

Table 1 Baseline Characteristics

\begin{tabular}{llllll}
\hline HM & \multicolumn{3}{l}{ migraine } & EA2 & CTR \\
\hline SPORADIC & FAMILIAR & MA & MO & & \\
36 & 14 & 36 & 36 & 15 & 70 \\
\hline
\end{tabular}

sequences of CACNA1A (NC_000019.9). All patients have been also screened for ATP1A2, SCN1A, PRRT2 mutations.

\section{MLPA and real time PCR}

Search of multi exon rearrangements was performed by MLPA assay using the P348-A2 ATP1A2-CACNA1A probe mix (SALSA MLPA Kit, MRC-Holland). Identification of deletion/duplications was confirmed by quantitative real -time PCR (qPCR). PCR reactions were carried out using a Biorad IQ5 (BioRad) in a 96-well optical plate with a final reaction volume of $50 \mu \mathrm{l}$. About $10 \mathrm{ng}$ of DNA were subjected to thermal cycling conditions with a pre-run of $2 \mathrm{~min}$ at $50{ }^{\circ} \mathrm{C}$ and $10 \mathrm{~min}$ at $95{ }^{\circ} \mathrm{C}$. Cycle conditions were 40 cycles at $95{ }^{\circ} \mathrm{C}$ for $15 \mathrm{~s}$ and $60{ }^{\circ} \mathrm{C}$ for $1 \mathrm{~min}$ according to the Sybr Green Real Time PCR Protocol (primers are available upon request). Analysis of relative gene expression data have been performed using real-time quantitative PCR and the $2-\Delta \Delta C T$ method [16], the starting copy number of the unknown samples was determined in comparison with the known copy number of the calibrator sample, using the $2-(\Delta \Delta \mathrm{Ct})$ method. As a reference gene, we used GAPDH. $P$ Values in patients were compared to results obtained in 70 normal individuals, deemed free of neurological disorders. All the experiments have been performed in triplicates.

\section{Microsatellite STR analysis}

All patients and healthy controls have been genotyped for the (CAG)n microsatellite markers. Accordingly to the already published method [17], all samples have been run by sequencer DNA analyser ABI 3031 (microsatellite analysis) and analysed by the Gene Mapper software.

\section{Results}

\section{Sequencing analysis}

Genetic analysis of the CACNA1A gene with direct sequencing, in a cohort of migraine sufferers (HM and MA/MO) identified 3 different point mutations (Table 2; Fig. 1a).

The first patient affected by FHM showed the missense mutation E1015K, already described in literature [18] as pathogenetic.

Next, we have identified two new mutations, not reported in literature or in disease databases. The first one is the missense variation Arg2157Gly (R2157G) that we found in a Moroccan hemiplegic migraine patient; unfortunately no relatives are available for segregation analysis (Fig. 1b). In silico analysis with Polyphen software (http://genetics.bwh.harvard.edu/pph2/) predicted the R2157G mutation as probably damaging with a score of 0.998. The pathogenity has been confirmed also by SIFT 
Table $\mathbf{2}$ List of detected point mutations and phenotypical features

\begin{tabular}{|c|c|c|c|c|c|c|c|c|}
\hline Patients & Mutation & $\begin{array}{l}\text { Present age } \\
\text { (yrs) }\end{array}$ & $\begin{array}{l}\text { Age of onset } \\
\text { (years) }\end{array}$ & Migraine/headache Features & Frequency & Duration (h) & $\begin{array}{l}\text { Cerebellar sign } \\
\text { and symptoms }\end{array}$ & $\begin{array}{l}\text { Other clinical } \\
\text { features }\end{array}$ \\
\hline $57 / 14$ & E1015K & 53 & 31 & Hemiplegic migraine & na & variable & no cerebellar & no \\
\hline $263 / 12$ & $\mathrm{I1512T}$ & 63 & 28 & Familiar Hemiplegic migraine & 1-2/week & variable & no cerebellar & no \\
\hline $203 / 08$ & I1512T & 46 & 18 & Familiar Hemiplegic migraine & 1-2/week & variable & no cerebellar & no \\
\hline 209/13 & R2157G & 39 & 21 & Familiar Hemiplegic migraine & na & variable & no cerebellar & no \\
\hline
\end{tabular}

and MutationTaster software (http://sift.jcvi.org/ and http://www.mutationtaster.org/).

The second novel missense mutation, I1512T, has been detected in heterozygosis in two brothers with FHM.

This variation has an amino acidic substitution corresponding to an Isoleucine into a Threonine, (I1512T) two essential amino acids that have a chiral side chain.

In silico analysis with Polyphen software predicted the I1512T mutation as probably damaging with a score of 0.999. These predictions were confirmed using Predict Protein (https://www.predictprotein.org).

\section{MLPA results}

The samples analysed showed the presence of an intragenic deletion in 9 subjects with sporadic hemiplegic migraine (18\%), in 3 patients with non-hemiplegic migraine (4.1\%) and in 3 patients affected by episodic ataxia (20\%) (Table 3).

Sporadic hemiplegic migraine: two patients showed a deletion in exons 41-43, while the rest of HM patients [5] showed a deletion in the terminal part of the $C A C$ $N A 1 A$ gene (ex 47).
Episodic ataxia: in a female EA patient (and her affected son) we identified a deletion in exon 12-15, while a second patient showed a deletion in exon 47 .

Migraine: the three deleted patients showed the same deletion in exon 47 , but two different phenotypes, as MA [1] and MO [2].

Also in one healthy control we have detected a deletion in exon 47.

\section{Microsatellites}

Expansion of the CAG repeat in the $\alpha 1 \mathrm{~A}$ subunit of the voltage-dependent calcium channel gene CACNA1A, leads to the Spinocerebellar ataxia type 6 (SCA6, MIM 183086). This is a late-onset, slowly progressive neurodegenerative disorder accounting for between 6 and 32\% of families with autosomal dominant ataxia [11]. None of the patients had expanded CAG repeats in the 3'-UTR of CACNA1A.

\section{Discussion}

Here we report an exhaustive screening of the CACNA1A gene in a large sample of 137 patients with four clinical phenotypes: FHM1, sporadic HM, EA2, MA and MO.

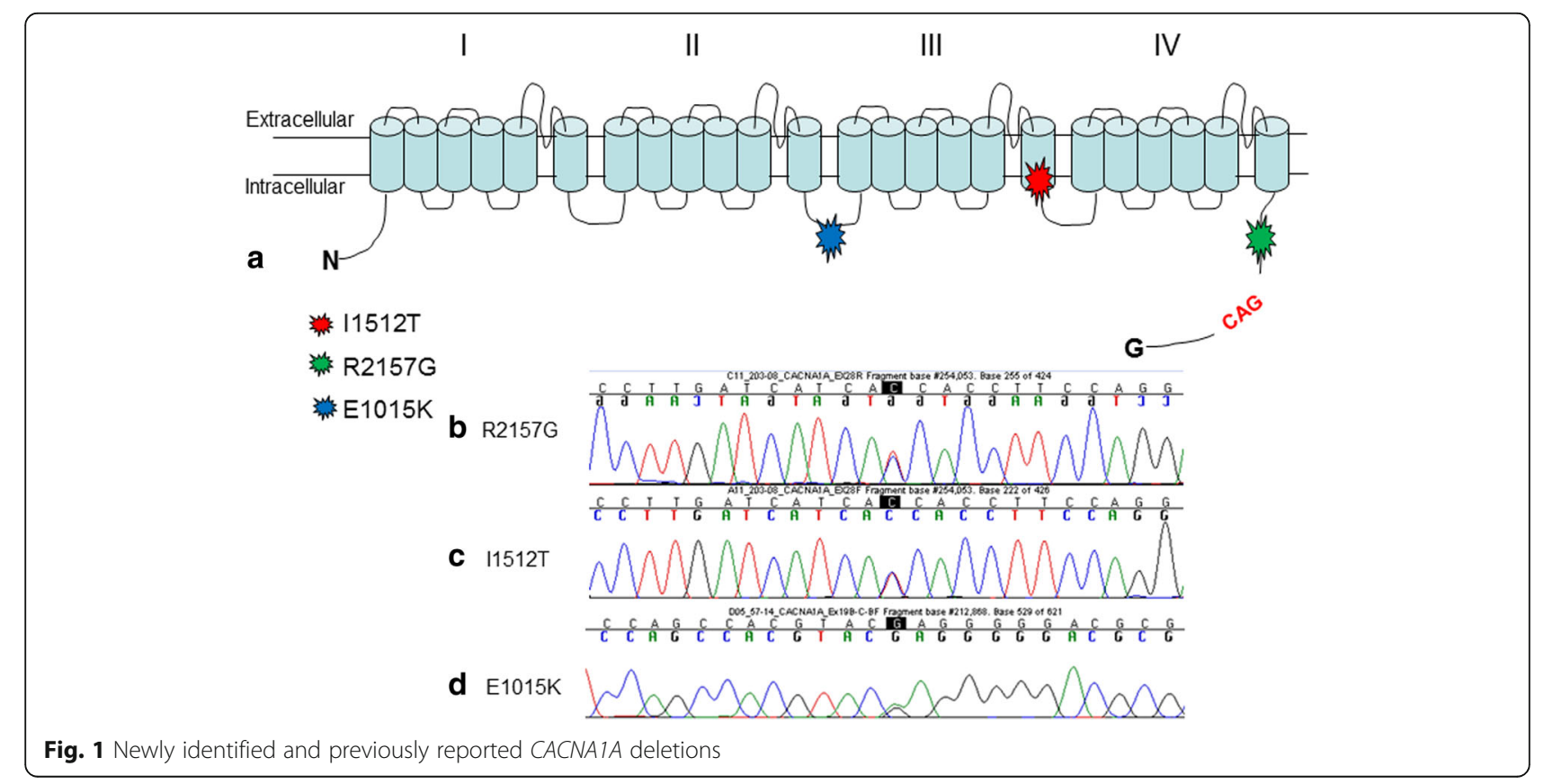


Table 3 Clinical Features

\begin{tabular}{|c|c|c|c|c|c|c|c|c|}
\hline Patients & Mutation & $\begin{array}{l}\text { Present } \\
\text { age (yrs) }\end{array}$ & $\begin{array}{l}\text { Age of onset } \\
\text { (years) }\end{array}$ & $\begin{array}{l}\text { Migraine/ } \\
\text { headache } \\
\text { Features }\end{array}$ & Frequency & Duration (h) & $\begin{array}{l}\text { Cerebellar sign } \\
\text { and symptoms }\end{array}$ & $\begin{array}{l}\text { Other clinical } \\
\text { features }\end{array}$ \\
\hline $16 / 11$ & del 41-43 & 17 & 14 & $\begin{array}{l}\text { Hemiplegic } \\
\text { migraine }\end{array}$ & 5/year & $12-48$ & No cerebellar & No \\
\hline $16 / 13$ & del $41-44$ & 42 & 12 & $\begin{array}{l}\text { Hemiplegic } \\
\text { migraine }\end{array}$ & 2/month & $1-2$ & No cerebellar & $\begin{array}{l}\text { Painful paresthesias } \\
\text { and mild cognitive } \\
\text { deficit }\end{array}$ \\
\hline $124 / 11$ & del 37-47 & 4 & 6 (months) & $\begin{array}{l}\text { Hemiplegic } \\
\text { migraine }\end{array}$ & 2/month & $2-3$ & No cerebellar & $\begin{array}{l}\text { Nystagmus, emiplegia, } \\
\text { distonia }\end{array}$ \\
\hline $72 / 12$ & del $45-47$ & 19 & 15 & $\begin{array}{l}\text { Hemiplegic } \\
\text { migraine }\end{array}$ & 6/year & $48-72$ & No cerebellar & Mild cognitive deficit \\
\hline $117 / 14$ & del $46-47$ & 39 & 33 & $\begin{array}{l}\text { Hemiplegic } \\
\text { migraine }\end{array}$ & 2/month & variable & No cerebellar & $\begin{array}{l}\text { Muscle pain and } \\
\text { fatigue, drop head, } \\
\text { loss of deambulation }\end{array}$ \\
\hline $12 / 15$ & del 47 & 42 & 23 & $\begin{array}{l}\text { Hemiplegic } \\
\text { migraine }\end{array}$ & 10/year & variable & No cerebellar & No \\
\hline $27 / 14$ & del 47 & 16 & 20 & $\begin{array}{l}\text { Hemiplegic } \\
\text { migraine }\end{array}$ & 12/year & $48-72 \mathrm{~h}$ & No cerebellar & No \\
\hline $118 / 14$ & del 47 & 23 & 17 & $\begin{array}{l}\text { Hemiplegic } \\
\text { migraine }\end{array}$ & 2-3/month & $2-3 h$ & No cerebellar & No \\
\hline $75 / 13$ & del 47 & 13 & 9 & $\begin{array}{l}\text { Hemiplegic } \\
\text { migraine }\end{array}$ & $2-3 /$ month & variable & No cerebellar & No \\
\hline $187 / 12$ & del 12-15 & 44 & 12 & Episodic ataxia (familiar) & $1-2 /$ month & $2-3 h$ & $\begin{array}{l}\text { Nystagmus in } \\
\text { horizontal and } \\
\text { vertical gaze and } \\
\text { mild cerebellar signs }\end{array}$ & $\begin{array}{l}\text { Monolateral } \\
\text { neurosensory } \\
\text { hearing loss }\end{array}$ \\
\hline $106 / 16$ & del 12-15 & 17 & 15 & $\begin{array}{l}\text { Episodic } \\
\text { ataxia } \\
\text { (familiar) }\end{array}$ & 1-2/week & variable & $\begin{array}{l}\text { Multidirectional } \\
\text { gaze evoked } \\
\text { nystagmus, } \\
\text { dysdiadochokinesis, } \\
\text { mild difficulty in } \\
\text { tandem walking }\end{array}$ & $\begin{array}{l}\text { Congenital } \\
\text { stationary } \\
\text { night blindness }\end{array}$ \\
\hline $165 / 14$ & del 47 & 6 & 1 & $\begin{array}{l}\text { Episodic } \\
\text { ataxia }\end{array}$ & $1 /$ month & variable & No cerebellar & No \\
\hline $195 / 12$ & del 47 & 14 & 7 & $\mathrm{MO}$ & 2/month & variable & No cerebellar & No \\
\hline $237 / 12$ & del 47 & 60 & 8 & MA & 6/year & $\begin{array}{l}\text { variable } \\
\text { (10 min } \\
\text { to } 48-72 \text { h) }\end{array}$ & No cerebellar & $\begin{array}{l}\text { Multifocal } \\
\text { leukoencephalopathy }\end{array}$ \\
\hline $80 / 11$ & del 47 & 38 & 9 & $\mathrm{MO}$ & 2-3/month & variable & No cerebellar & No \\
\hline
\end{tabular}

The study was addressed through Next Generation Sequencing and MLPA analyses in the patients.

In the last years an increasing number of point mutations in CACNA1A have been reported as causative of FHM-1 and EA2 [19, 20].

In our cohort of patients, Sanger analysis identified only three point mutations in the CACNA1A gene; the E1015K, previously described associated with different migraine phenotypes [18], was identified in a patient with a clinical diagnosis of Hemiplegic migraine without family history.

Two novels variations (I1521T, R2157G) have been detected in three unrelated patients with FHM and in silico studies predicted both the variations as damaging.
Patients with EA2 and MA/MO phenotypes resulted negative to sequencing analysis, suggesting that other genes, known to be causative of FHM such as ATP1A2, SNC1A and PRRT2, could be involved and are worth to be screened. Our results expand the number of small mutations of CACNA1A gene associated with HM/FHM phenotype but on the other hand highlight the need to carry out a second level analysis to search for gross genomic rearrangement.

Therefore, in our cohort of patients negative to Sanger sequencing, we performed MLPA analysis of CACNA1A gene and we found different deletions in the C-terminus region of the gene. 
19p13.1 - CACNA1A

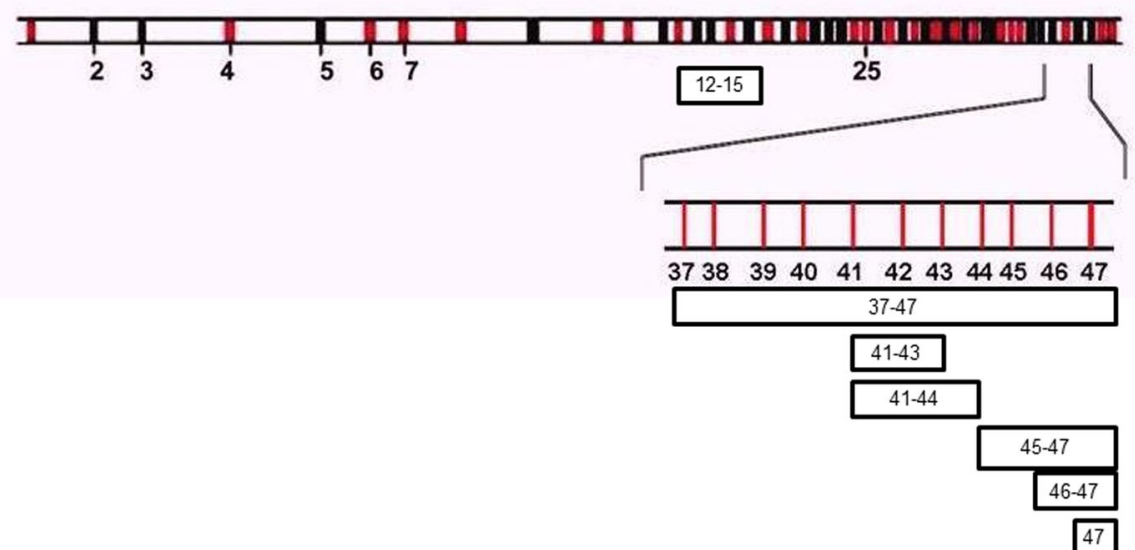

Fig. 2 CACNA1A deletions

To date, deletions in the CACNA1A gene have been reported in literature but associated exclusively to an EA2 phenotype.

Riant and collaborators [8] described a deletion spanning from exon 38 to 40 and removing 105 amino acids in the proximal half of the cytoplasmatic $\mathrm{C}$-terminal tail of the protein, that is essential for channel function. This result has been reported also by others $[9,10]$.

We identified a novel deletion of exons $12-15$ in a female patient with EA2 and in her son affected by congenital night blindness. The deletion of $12-15$ exons is out of frame and predicts to cause premature truncation of the CACNA1A protein product; or its complete absence via mRNA decay.

The novelty of this report is the intrafamilial phenotypic variability associated to the same deletion, giving rise to a classical EA2 in the mother and to a more complex phenotype in the son.

A part from this family, in patients with migraine (HM, MA and MO), we have detected different deletions in the 3' end of CACNA1A (Fig. 2).

Deletions of more than one exon were present only in patients with sporadic HM, instead the single exon 47 deletion was found associated to different clinical presentations: HM (four cases), EA2 (one case), MO (two cases) and MA (one case).

The high frequency of exon 47 deletion in our cohort lead us to speculate if it might be a polymorphism or a mutational hot spot, harbouring also the triplet repeat involved in the pathogenesis of SCA6.

We have detected the single exon 47 deletion in one subject of the controls cohort and in this subject, clinical investigation was negative for neurological involvement and he did not refer migraine; we cannot exclude a low penetrance of the deletion in this patient or that he will manifest clinical signs in the years to come.Further investigation and functional studies are necessary to better understand the role of CACNA1A exon 47 deletion in migraine disorders.

Our findings expand the spectrum of clinical phenotype associated with deletions in the $3^{\prime}$ end of CACNA1A gene. Interestingly, all our deleted patients manifested early motor and headache symptoms in the juvenile period or even in preteen years. If this correlate to the specific function of the gene product during development is unclear, although mutations in other FHM genes (ATP1A2 and SCN1A) may occur frequently in episodic ictal brain dysfunctions in childhood. The other reports of deletions in CACNA1A gene are in keeping with these findings, suggesting that deletions in the gene are associated with an onset of clinical manifestations before the age of $30[8,9]$.

\section{Conclusions}

In conclusion, the four clinical phenotypes we have included in this study (FHM1, sporadic HM, EA2, MA and $\mathrm{MO}$ ) should be considered part of the same disease spectrum and for this group of diseases it should be kept in mind the genetic and allelic heterogeneity and also the intrafamilial / interfamilial clinical variability.

Moreover, in patients with migraine phenotypes and episodic ataxia is becoming mandatory the screening of gross rearrangements of CACNA1A gene for a complete genetic workup.

\section{Abbreviations}

CACNA1A: Calcium voltage-gated channel subunit alpha1 A; FHM: Familiar Hemiplegic Migraine; MA: Migraine with Aura; MO: Migraine without Aura 


\section{Acknowledgements}

We thank all patients and familiar for the contribution to this research project.

\section{Funding}

This work was funded by Italian Ministry of Health (RC2013-2016).

\section{Availability of data and materials}

Yes

\section{Authors' contributions}

GGS and GS run all the experiments, GS wrote the manuacript. RC, NM and GF counseled patients. NG, FA and CC revised the paper. PO revised the resubmitted manuscript. All authors read and approved the final manuscript.

\section{Ethics approval and consent to participate}

Yes

\section{Consent for publication}

Yes

\section{Competing interests}

The authors declare that they have no competing interests.

\section{Publisher's Note}

Springer Nature remains neutral with regard to jurisdictional claims in published maps and institutional affiliations.

\section{Author details}

${ }^{1}$ IRCCS Mondino Foundation, Genomic and post-Genomic Center, Pavia, Italy. ${ }^{2}$ Unit of Medical Genetics, S. Anna University-Hospital, Ferrara, Italy. ${ }^{3}$ IRCCS Mondino Foundation, Headache Science Center, Pavia, Italy.

Received: 4 May 2018 Accepted: 20 July 2018

Published online: 30 August 2018

\section{References}

1. Jodice C, Mantuano E, Veneziano L, Trettel F, Sabbadini G, Calandriello L, Francia A, Spadaro M, Pierelli F, Salvi F, Ophoff RA, Frants RR, Frontali M (1997 Oct) Episodic ataxia type 2 (EA2) and spinocerebellar ataxia type 6 (SCA6) due to CAG repeat expansion in the CACNA1A gene on chromosome 19p. Hum Mol Genet 6(11):1973-1978

2. Mantuano E, Veneziano L, Jodice C, Frontali M (2003) Spinocerebellar ataxia type 6 and episodic ataxia type 2: differences and similarities between two allelic disorders. Cytogenet Genome Res 100(1-4):147-153 Review

3. Romaniello R, Zucca C, Tonelli A, Bonato S, Baschirotto C, Zanotta N, Epifanio R, Righini A, Bresolin N, Bassi MT, Borgatti R (2010) A wide spectrum of clinical, neurophysiological and neuroradiological abnormalities in a family with a novel CACNA1A mutation. J Neurol Neurosurg Psychiatry 81(8):840-843

4. Pradotto L, Mencarelli M, Bigoni M, Milesi A, Di Blasio A, Mauro A (2016) Episodic ataxia and SCA6 within the same family due to the D302N CACNA1A gene mutation. J Neurol Sci 371:81-84

5. Carreño O, Corominas R, Serra SA, Sintas C, Fernández-Castillo N, Vila-Pueyo M, Toma C, Gené GG, Pons R, Llaneza M, Sobrido MJ, Grinberg D, Valverde MÁ, Fernández-Fernández JM, Macaya A, Cormand B (2013) Screening of CACNA1A and ATP1A2 genes in hemiplegic migraine: clinical, genetic, and functional studies. Mol Genet Genomic Med 1(4):206-222

6. Silberstein SD, Dodick DW (2013) Migraine genetics: part II. Headache 53(8): 1218-1229 Review

7. Pelzer N, de Vries B, Kamphorst JT, Vijfhuizen LS, Ferrari MD, Haan J, van den Maagdenberg AM, Terwindt GM (2014) PRRT2 and hemiplegic migraine: a complex association. Neurology 83(3):288-290

8. Riant F, Lescoat C, Vahedi K, Kaphan E, Toutain A, Soisson T, Wiener-Vacher SR, Tournier-Lasserve E (2010 Feb) Identification of CACNA1A large deletions in four patients with episodic ataxia. Neurogenetics 11(1):101-106

9. Labrum RW, Rajakulendran S, Graves TD, Eunson LH, Bevan R, Sweeney MG, Hammans SR, Tubridy N, Britton T, Carr LJ, Ostergaard JR, Kennedy CR, AlMemar A, Kullmann DM, Schorge S, Temple K, Davis MB, Hanna MG (2009 Nov) Large scale calcium channel gene rearrangements in episodic ataxia and hemiplegic migraine: implications for diagnostic testing. J Med Genet 46(11):786-791

10. Wan J, Mamsa H, Johnston $J$, Spriggs EL, Singer HS, Zee DS, Al-Bayati AR, Baloh RW, Jen JC, CINCH Investigators (2011) CINCH investigators large genomic deletions in CACNA1A cause Episodic Ataxia Type 2. Front Neurol 2:51

11. Dichgans M, Schols L, Herzog J, Stevanin G, Weirich-Schwaiger H, Rouleau G, Burk K, Klockgether T, Zuhlke C, Laccone F, Riess O, Gasser T (1999) Spinocerebellar ataxia type 6: evidence for a strong founder effect among German families. Neurology 52:849-851

12. Denier C, Ducros A, Vahedi K, Joutel A, Thierry P, Ritz A, Castelnovo G, Deonna T, Gérard P, Devoize JL, Gayou A, Perrouty B, Soisson T, Autret A, Warter JM, Vighetto A, Van Bogaert P, Alamowitch S, Roullet E, TournierLasserve E (1999) High prevalence of CACNA1A truncations and broader clinical spectrum in episodic ataxia type 2. Neurology 52(9):1816-1821

13. Jen JC, Kim GW, Dudding KA, Baloh RW (2004) No mutations in CACNA1A and ATP1A2 in probands with common types of migraine. Arch Neurol 61(6):926-928

14. Graves TD, Hanna MG (2008) Episodic ataxia: SLC1A3 and CACNB4 do not explain the apparent genetic heterogeneity. J Neurol 255(7):1097-1099

15. Mantuano E, Romano S, Veneziano L, Gellera C, Castellotti B, Caimi S, Testa D, Estienne M, Zorzi G, Bugiani M, Rajabally YA, Barcina MJ, Servidei S, Panico A, Frontali M, Mariotti C (2010) Identification of novel and recurrent CACNA1A gene mutations in fifteen patients with episodic ataxia type 2. J Neurol Sci 291(1-2):30-36

16. Livak KJ, Schmittgen TD (2001) Analysis of relative gene expression data using real-time quantitative PCR and the 2(-Delta Delta C(T)) method. Methods 25(4):402-408

17. Zeng A, Liu X, Shen L, Li W, Ding Z, Bai Y, Lu J (2012) Analysis of mitochondrial DNA variations in a Chinese family with spinocerebellar ataxia. J Clin Neurosci 19(1):60-64

18. Condliffe SB, Fratangeli A, Munasinghe NR, Saba E, Passafaro M, Montrasio C, Ferrari M, Rosa P. Carrera PJ (2013 Nov 22) The E1015K variant in the synprint region of the CaV2.1 channel alters channel function and is associated with different migraine phenotypes. Biol Chem 288(47):3387333883

19. De Vries B, Frants RR, Ferrari MD, van den Maagdenberg AM (2009) Molecular genetics of migraine. Hum Genet 126(1):115-132

20. Nachbauer W, Nocker M, Karner E, Stankovic I, Unterberger I, Eigentler A, Schneider R, Poewe W, Delazer M, Boesch S (2014) Episodic ataxia type 2: phenotype characteristics of a novel CACNA1A mutation and review of the literature. J Neurol 261(5):983-991 Review
Ready to submit your research? Choose BMC and benefit from:

- fast, convenient online submission

- thorough peer review by experienced researchers in your field

- rapid publication on acceptance

- support for research data, including large and complex data types

- gold Open Access which fosters wider collaboration and increased citations

- maximum visibility for your research: over $100 \mathrm{M}$ website views per year

At BMC, research is always in progress.

Learn more biomedcentral.com/submissions 